\title{
Impact of Selected Economic Indicators on Foreign Investment Inflow in Nigeria and South Africa: Optimal Indicators Search
}

\author{
Onuorah Anastasia Chi-Chi (MBA, M.Sc) \\ Department of Accounting, Banking and Finance, \\ Delta State University, Asaba Campus, Delta State, Nigeria \\ E-mail: anastasiaonuorah@yahoo.com \\ Nzotta Samuel Mbadike (PhD) \\ Department of Management Technology, \\ Federal University of Technology, Owerri, Imo State, Nigeria \\ E-mail: uunzotta@yahoo.com \\ Ozurumba Benedict Anayachukwu (PhD) \\ Department of Management Technology, \\ Federal University of Technology, Owerri, Imo State, Nigeria \\ E-mail: OzurumbaBenedict@yahoo.com \\ Chigbu Emmanuel Ezeji (PhD) \\ Department of Management Technology, \\ Federal University of Technology, Owerri, Imo State, Nigeria \\ E-mail: sussychigbu@yahoo.com
}

\begin{abstract}
Search for ways of attracting foreign investment into developing countries raises great interest among researchers and therefore, there is a search for the economic indicators affecting foreign investment appeal in Africa. This study focuses on the impact of economic indicators of Banking Sector Development Model on foreign investment inflows in Nigeria and South Africa. Various data on banking sector; economic indicators of the classified model were sourced from state statistical bulletins as well as World Bank for the year of 1980-2013. The analysis employed several econometric tools: Unit root, Co-integration, VAR estimates of relative and global statistics to measure the impact and significance of economic indicators attracting/repelling foreign investments. Akaike information criteria for best model selection results showed that economic indicators of Banking Sector Development Model in Nigeria attracted more foreign investment than it did in South Africa. The study concluded that the optimal economic indicators attracting foreign investment are domestic credit and inflation rate. Therefore, the study recommended that effort is highly needed by the government to promote sustainable domestic credit facilities to local industries to attract foreign investment and there should be proactive efficient interest rate control to encourage loans and advances in these two countries.
\end{abstract}

Keywords: Banking sector, economic indicators, foreign investment, inflation, domestic credit, loans, return on investment

\section{Introduction}

Over the years, African countries had been unable to attract adequate foreign investment inflows due to poor economic background. According to Okogwu (1989), this was because Africa had no strategic financial investment policies or coherent guidelines to attract adequate foreign investment inflows reflected by the poor and undeveloped nature of the nation prior to their independence. Treisman (2007), Chung and Lin (2004) advanced more reasons; African countries are vulnerable to volatile weather situations, poor infrastructural conditions and political instability in the continent. Many African countries are also facing difficulties in reducing high rates of poverty. In most countries of the developing world, domestic market demand is not large enough to attract large foreign investments coupled with lack 
of trade liberalization, high premium on currencies and price instability, underdeveloped capital market, unstable investment policies and high collateral demand by banks.

Despite Africa experienced financial turn down, most African countries introduced vibrant financial investment policy reforms and strategic investment incentives some decades after their independence; they gradually built positive changes in the growth and in the potentials of African's foreign investment inflows. According to Harsch (2014), Africa remains as a major partner in doing business because it is believed that the workforce in Africa is young and energetic; economic growth is also feasible. There are facilities for other countries to invest in African countries, especially, in Nigeria and South Africa. The scope of the study covers two selected countries in Africa (Nigeria and South Africa) and the data is based on secondary sources (1980-2013). Thus, purpose of the study is to investigate the impact of banking sector economic indicators on foreign investment inflows (FI) using data from 1980-2013, to examine the impact of the economic indicators attracting foreign investment inflows and to determine the optimal model of economic indicators for foreign investment inflows in Nigeria and South Africa.

\section{Literature review}

Investment, according to Osiegbu and Onuorah (2011), is defined as commitment of fund to a given economic activities in anticipation for future benefits or future consumption, or as the process of postponing immediate consumption in anticipation for future benefits. Nzotta (2005) sees investment as an asset held by business for the creation of further wealth, such as interest, royalties, dividends and rents, etc. (e.g capital appreciation (capital gain) or benefits to the investor). Akujuobi (2006) sees investment in the form of financial assets or real assets. Nwezeaku (2005) defines investment as any property, project or human endeavour for which one hopes for a return. Nwezeaku (2005) postulated that domestic investment is investment in the companies and products of someone's own country rather than those of foreign countries.

Most of the literature reviewed so far proves benefits of identifying the research issues, which are mainly the springboard on which the objectives of this study are based on. Studies by Anupam and Krishna (2002), Menike (2006), Onuorah and Okoli (2013), Leonce (2005), Arshad and Zafar (2010), Mohamed (2009), Onuorah and Akujuobi (2013) and Oladipo (2013) presented empirical evidence on determinant of foreign direct investment (FDI) or foreign portfolio investment (FPI) respectively. Findings from these studies have also established an increase of FDI and FPI inflow into these respective economies. Studies have shown that there have been potential inflows of foreign investment into Nigerian and South African economies and the outcome can be evidenced in their recent ranking as growing and expanding economy in Africa. However, the interest of this present study is not only to confirm the findings of past research in respect to increase in foreign investment but also to establish specific macroeconomic variables capable of increasing potential for more inflows. It is against this background that the researcher adopted five aggregated macroeconomic variables to capture banking sector impact, capital market impact, trade liberalization impact, taxation impact and sectorial GDP contribution impact on foreign investment inflows within the review period $(1980-2013)$ in Nigeria and South Africa countries.

\subsection{Economic indicators and model development review}

In this study, some models are developed with specific indicators to classify variables and evaluate their impact on foreign investment. The base of the specified model is reviewed below:

\subsubsection{Banking sector development}

In developing banking sector stability index for Nigeria, Angela et.al, (2014) adopts approach from Nicholas and Isabel (2010) to construct the Banking Sector Stability Index (BSSI) for Nigeria; evaluation of the impact of the country's financial strength, development of external sector, real sector and financial sector variables to its growth. The result revealed a positive and significant relationship between the dependent and independent variables.

Ali (2012) studied banking sector development on economic growth in Lebanon using credit to local private sector and deposit growth. The research focused on size, efficiency and concentration of banking sector in relation to their impact on economic growth. The causality test result indicated that assets Granger caused GDPG and GDPG Granger caused credit in short run. It further confirmed that demand-following relationship was evident between banking sector development and economic growth in Lebanon. This review gives this study a direction of selecting variables such as inflation, credit to GDP and growth rate; some indicators of World Bank Economic Development. Thus, the Banking Sector Development (BSD) is a function of domestic credit (DC), interest rate (INT), loans and advances (LOA) and 
return on investment (ROI). Some other selected variables are from Angel et al (2014). Hence, the functional form for BSD and model specification of FI becomes as below:

\section{Model 1: Banking sector development model}

$$
\begin{aligned}
& F I=f(B S D) \\
& B S D=f(L O A, I N T, D C, R O I) \\
& \text { Therefore } F I=f(L O A, I N T, D C, R O I)
\end{aligned}
$$

Where: FI - foreign investment, BSD - banking sector development, LOA - Loans and Advances, DC - domestic credit, INT - interest rate and ROI - Return on Investment. In this study, the log functional form and model adopted for the empirical study is stated as follow:

\section{Model of BSD on FI}

$$
\begin{aligned}
& \operatorname{LnNFI}_{t}=\beta_{0}+\beta_{1} \sum_{i=1}^{n} \operatorname{LnNLOA}_{t-i}+\beta_{2} \sum_{i=1}^{n} \operatorname{LnNINT}_{t-1}+\beta_{3} \sum_{i=1}^{n} \operatorname{LnNDC}_{t-1}+\beta_{4} \sum_{i=1}^{n} \operatorname{LnNROI}_{t-1}+\operatorname{Var}(\delta)+\varepsilon_{t} \\
& \operatorname{LnSFI}_{t}=\beta_{0}+\beta_{1} \sum_{i=1}^{n} \operatorname{LnSLOA}_{t-i}+\beta_{2} \sum_{i=1}^{n} \operatorname{LnSINT}_{t-1}+\beta_{3} \sum_{i=1}^{n} \operatorname{LnSDC}_{t-1}+\beta_{4} \sum_{i=1}^{n} \operatorname{LnSROI}_{t-1}+\operatorname{Var}(\delta)+\varepsilon_{t}
\end{aligned}
$$

(Equation 1 and 2)

Where $L n=$ natural logarithm, $\beta_{0}$ is constant term, $\beta_{1}-\beta_{5}$ are the coefficient values or parameter values, $\operatorname{Var}(\delta)$ is the vector parameter for long run equilibrium and the $\varepsilon_{t}=$ is error term. In defining variable for analysis, prefixes such as $\mathrm{N}$ and $\mathrm{S}$ shall accompany the indicators for each of the models measuring FI for Nigeria and South Africa respectively. The variables in equations 1 to 5 from the functions are used for the data analysis procedure by natural logarithmic transformation and apply for the individual country of study for ease of econometrics estimation procedures and interpretation. The data for the analysis is expressed in natural logarithmic form like $\operatorname{LnFI}-\log _{\mathrm{e}}$ (Foreign Investment) but is shown in the model as FI .

\subsection{A priori expectations}

The presumptive signs or the a priori expectations for model equations are interpreted as: For Banking Sector Development Model, the coefficient of Loan and Advances (LOA), Domestic Credit (DC), Return on Investment (ROI) are expected to be greater than zero indicating direct relationship of Banking Sector Development Model (BSD) indicators with Foreign Investment (FI) in Nigeria and South Africa i.e $\beta_{1}, \beta_{3}, \beta_{4}>0$. However, the coefficient of Interest rate (INT) is expected to be negative i.e $\beta_{2}<0$.

\section{Research methods}

The triangulation method of data collection is used to collect data for the research study. Institutions such as World Bank Development Indicators (2013), Central Bank of Nigeria (CBN), Nigeria State Statistics (2013), South Africa State Statistics (2013), International Monetary Fund (IMF, 2013), Ministry of Finance, National Treasury of the Republic of South Africa (2014) were consulted for data generation and improved data quality source for data analysis. The major techniques used for this analysis are Stationarity Test of time series data, Johansen Multivariate Cointegration Test, Vector Autoregressive Model or Unrestricted VAR Model.

\subsection{Data analysis technique}


Data were sourced from the World Bank statistical data base, Central bank of Nigeria, Nigeria Statistical Bulletin 2013 as well as South Africa Statistical Bulletin 2013. Various empirical analyses were performed using Johansen Cointegration to test for the properties of the time series variables.

The time series and cross sectional data (pooled data) in this study was fitted into regression function to determine the relationship between economic indicators of Banking Sector Development and foreign investment in Nigeria and South-Africa; econometrics techniques such as unit root test was used to determine level or order of Stationarity model. Johansen co integration was used to determine the order of integration to identify long run equilibrium relationship between the model indicators and foreign investment. In addition, Vector auto regression model (VAR) is the main estimate procedure adopted to find out the relative and global statistics of each of the model. An Akaike information criterion is used to identify model performance in these two countries. Finally, the directional causal relationship among model indicators of foreign investment adopted Granger causality test to verify the impact of the model indicators of foreign investment in Nigeria and South Africa respectively.

\section{Analysis and results}

\subsection{Diagnostic test and analysis}

The Diagnostic test applied in this study are autocorrelation, heteroskedasticity, normality test and stability test of models.

Table 4-1 Results of Diagnostic Test of Banking Sector Model for Nigeria and South Africa

\begin{tabular}{|l|l|l|l|}
\hline \multicolumn{2}{|l|}{ Test Statistics } & \multicolumn{1}{|c|}{$\begin{array}{c}\text { Model for } \\
\text { Nigeria }\end{array}$} & $\begin{array}{c}\text { Model for } \\
\text { South Africa }\end{array}$ \\
\hline Diagnostic Check & Test & BSD & BSD \\
\hline Autocorrelation & Durbin Watson- & 1.94 & 2.91 \\
& Serial Correlation & 0.99 & 0.89 \\
\hline Heteroskedasticity & Breusch-Pagan L.M & 0.719 & 0.619 \\
\hline Normality & Jacque-Bera & 1011.67 & 923.67 \\
& Prob. & 0.210 & 0.115 \\
\hline Stability & Ramsey Reset Prob. & 0.952 & 0.952 \\
\hline
\end{tabular}

Source: E-views 7.0 Extraction, 2014

Diagnostic test for Nigeria and South Africa model was used to dictate two test for autocorrelation error such as Durbin Watson and Breusch-Godfrey serial correlation L.M tests. The Durbin Watson D-statistics is 1.94 for Nigeria and 2.91 for South Africa. Since these numbers lie between accepted range, there is no autocorrelation problem in the banking sector development problem (BSD).

Moreover, the probability of F-statistics of Breusch-Godfrey serial correlation L.M test from table 4.1 shows 0.99 for Nigeria and 0.89 for South Africa that are higher than 5\% level of significance. The hypothesis cannot be rejected proving that there are no serial correlation problems among the five models. After these two tests, autocorrelation error was not detected and the models are good for prediction for foreign investment in Nigeria and South Afrika.

There is Breusch-Pagan L.M test to detect heteroskedasticity error; the probabilities of F-statistic of the model is 7.19 for Nigeria and 0.619 for South Africa. The p-values are higher than 5\% significant level, so the null hypothesis cannot be rejected proving that there is no problem of heteroskedasticity in banking sector development.

The associated probability values of Jarque-Bera statistic is 0.210 for Nigeria and 0.115 for South Africa. This implies that model BSD have probability greater than 5\% significant level.

Model stability test using Ramsey reset F-statistic indicates that the p-values for model residuals is 0.952 for Nigeria and South Africa. This shows that BSD model is in functional form. Therefore, BSD model is a good prediction and estimation for empirical analysis for foreign investment inflow study.

Table 4.2: Results of Unit Root Test for Nigeria

\begin{tabular}{llllll}
\hline Models & Variable & Order & ADF & $\begin{array}{l}\text { Critical } \\
\text { value }\end{array}$ & $\begin{array}{l}\text { ADF }>C / \\
\text { Value }\end{array}$
\end{tabular} Conclusion At




\begin{tabular}{|c|c|c|c|c|c|c|c|c|}
\hline & NFI & $\mathrm{I}(0)$ & -3.2164 & -2.9571 & $\begin{array}{l}\text { No } \\
\text { root }\end{array}$ & unit & Stationary & Level \\
\hline \multirow[t]{2}{*}{$\begin{array}{c}\text { Model } \\
\text { 1: }\end{array}$} & NLOA & $\mathrm{I}(0)$ & -3.6691 & -2.9571 & $\begin{array}{l}\text { No } \\
\text { root }\end{array}$ & unit & Stationary & Level \\
\hline & NINT & $\mathrm{I}(1)$ & -6.8531 & -2.9604 & $\begin{array}{l}\text { No } \\
\text { root }\end{array}$ & unit & Stationary & $1^{\text {st }}$ diff. \\
\hline \multirow[t]{3}{*}{ BSD } & NDC & $\mathrm{I}(0)$ & -5.7496 & -2.9540 & $\begin{array}{l}\text { No } \\
\text { root }\end{array}$ & unit & Stationary & Level \\
\hline & NROI & $\mathrm{I}(1)$ & -3.2275 & -2.9540 & $\begin{array}{l}\text { No } \\
\text { root }\end{array}$ & unit & Stationary & $1^{\text {st }}$ diff. \\
\hline & SFDI & $\mathrm{I}(1)$ & -6.6634 & -2.9639 & $\begin{array}{l}\text { No } \\
\text { root }\end{array}$ & unit & Stationary & $1^{\text {st }}$ diff. \\
\hline $\begin{array}{c}\text { Model } \\
\text { 1: }\end{array}$ & SINT & $\mathrm{I}(0)$ & -4.1286 & -2.954 & $\begin{array}{l}\text { No } \\
\text { root }\end{array}$ & unit & Stationary & $1^{\text {st }}$ diff. \\
\hline \multirow[t]{3}{*}{ BSD } & SLOA & $\mathrm{I}(1)$ & -5.1801 & -2.9571 & $\begin{array}{l}\text { No } \\
\text { root }\end{array}$ & unit & Stationary & Level \\
\hline & SDC & $\mathrm{I}(0)$ & -6.9965 & -2.9571 & $\begin{array}{l}\text { No } \\
\text { root }\end{array}$ & unit & Stationary & $1^{\text {st }}$ diff. \\
\hline & SROI & $\mathrm{I}(1)$ & -4.2886 & -2.954 & $\begin{array}{l}\text { No } \\
\text { root }\end{array}$ & unit & Stationary & $1^{\text {st }}$ diff. \\
\hline
\end{tabular}

Source: E-Views7.1 Result Summary Output, 2014

The result from table 4.2 of the unit root test above summarizes the unit root test of the variables to examine the stationarity of variables over time. Augmented Dickey Fuller Test (ADF-Test) results confirmed that the variables of Foreign Investment (NFI), Loan and Advances (NLOA) and Domestic Credit (NDC) are stationary at level I (0) since the ADF values are far greater than the critical values at 5\% level. In addition, Interest Rate (NINT), Return on Investment (NROI), South Africa foreign investment (SFI), Loan and Advances (SLOA) and Domestic Credit (SDC) and Return on Investment (SROI) are stationary at level I (1) since the ADF values are far greater than the critical values at 5\% level. These results of unit root tests of each variable suggests that there is no presence of unit root as $\mathrm{ADF}$ values are greater than the critical value of $5 \%$. All the variables are stationary.

Table 4.3: Results of Johansen Co integration Test for Models on FI- Nigeria

\begin{tabular}{|c|c|c|c|c|c|c|}
\hline $\begin{array}{l}\text { Model } \\
\text { on FI }\end{array}$ & $\begin{array}{l}\text { Model } \\
\text { Name }\end{array}$ & $\begin{array}{l}\text { Eigen } \\
\text { Values }\end{array}$ & $\begin{array}{l}\text { Trace } \\
\text { Statistics }\end{array}$ & $\begin{array}{l}0.05 \\
\text { Critical value }\end{array}$ & Prob*** & $\begin{array}{l}\text { Hypothesized } \\
\text { No. of Co- } \\
\text { integrating } \\
\text { Equations (C.E) }\end{array}$ \\
\hline
\end{tabular}

\begin{tabular}{|c|c|c|c|c|c|c|}
\hline Nigeria & BSD & 0.3018 & 35.0167 & 29.7971 & 0.0021 & At most $1 *$ \\
\hline South Africa & BSD & 0.5498 & 47.7897 & 27.8561 & 0.0007 & None* \\
\hline
\end{tabular}

Trace test indicates co-integrating equation (s) at the 0.05 level * denotes rejection of the hypothesis at the 0.05 level **MacKinnon-Haug-Michelis (1999) p-values Source: E-Views statistical package version 7

Empirical results from table 4.3 indicates that Johansen Co-integration test for all the models for foreign investment in Nigeria reveal that both the maximum eigenvalue and trace tests statistics (L.R) have values greater than the critical values at 5 percent levels of significance $(* *)$. Therefore, the null hypotheses of co-integrating vectors $(r=0 ; r \leq 1)$ against the specific alternatives are clearly rejected. Banking sector development (BSD) is co-integrated at most $1 *$ indicating at least 2 co-integrating equations for Nigeria. BSD is co-integrated at none*. This implies at least 1 cointegrating equation in South Africa. Therefore, the test presents clear evidence that there are long run equilibrium relationships among macroeconomic variables and foreign investment in Nigeria and Nigeria. 
Table 4.4: Results of VAR Model Relative Statistics of BSD Model for Nigeria and South Africa

\begin{tabular}{|c|c|c|c|c|c|c|c|}
\hline & \multicolumn{6}{|c|}{ Relative Statistics } & \multirow[b]{2}{*}{ Note } \\
\hline \multirow[t]{2}{*}{$\begin{array}{l}\text { Dependent: } \\
\text { FI }\end{array}$} & \begin{tabular}{|l|} 
BSD \\
Variables
\end{tabular} & Coef. $(\beta)$ & $\mathbf{S E}(\beta)$ & T-statistic & $\begin{array}{l}\text { '2-t' sig. } \\
\text { at } 5 \%\end{array}$ & $\begin{array}{l}\text { T-stat >'2-t' sig. } \\
\text { at 5\% }\end{array}$ & \\
\hline & NLOA & 0.3212 & 0.8546 & 0.5719 & '2-t' sig. & Not significant & \\
\hline \multirow[t]{9}{*}{ Nigeria } & NINT & 0.0612 & 0.1557 & 1.5846 & '2-t' sig. & Not significant & \\
\hline & NDC & 0.1927 & 0.0854 & -2.2570 & '2-t' sig. & Significant** & \\
\hline & NROI & -0.0102 & 0.3289 & -0.3455 & '2-t' sig. & Not significant & \\
\hline & NFI(-1) & 0.3306 & 0.1825 & 1.5319 & ' $2-t$ ' sig. & Not significant & \\
\hline & NFI(-2) & 0.0349 & 0.0487 & 1.3205 & '2-t' sig. & Not significant & \\
\hline & $\mathrm{C}$ & 6.3594 & & & & & \\
\hline & SLOA & -0.0081 & 0.5099 & -0.0159 & '2-t' sig. & Not significant & \\
\hline & SINT & 1.8468 & 2.4818 & 0.7441 & '2-t' sig. & Not significant & \\
\hline & SDC & 2.264 & 0.8765 & 2.5871 & '2-t' sig. & Significant & $* *$ \\
\hline \multirow[t]{4}{*}{ South Africa } & SROI & -1.5501 & 2.0845 & -0.7433 & '2-t' sig. & Not significant & \\
\hline & SFI(-1) & -0.5419 & 0.1917 & 2.8269 & '2-t' sig. & It is significant & $* *$ \\
\hline & SFI(-2) & -0.3721 & 0.1786 & -2.0836 & '2-t' sig. & It is significant & $* *$ \\
\hline & $\mathrm{C}$ & -122.55 & & & & 6 & \\
\hline
\end{tabular}

**Sig. if t-stat>'2-t' sig., Source: E-Views statistical package version 7

From the VAR model estimate in table 4.4 above, the Banking Sector Development Model of FI reveals that the indicators for Nigeria show that the estimate of $\beta_{1}$ is 0.3212 . This means that there is positive relationship between the loan and advances (NLOA) and foreign portfolio investment in Nigeria. Changes in the value of NLOA result in the Nigerian NFPI increase by 0.32 . The estimate of $\beta_{2}(0.0612)$ indicates that there is a direct relationship between Interest rate (NINT) and Foreign Investment (NFI). This result shows that a unit change in Interest rate (NINT) will account for about 0.06 increase on foreign investment (NFPI); if foreign investment (NFI) increases by a unit, interest rate (NINT) increases by the same magnitude. The coefficient of $\beta_{3}=0.1927$ represents the estimated value of domestic credit (NDC). It shows positive relationship between foreign investments (NFI) and domestic credit (NDC). Therefore, a unit change in NDC results in 0.14 increases in foreign investment (NFI). Return on investment (NROI) has estimated coefficient of $\beta_{4}=-0.0102$ indicating negative relationship between NROI and NFI. Change in NROI will result in 0.01 decrease in NFI in Nigeria. The value of FI (-1) and FI (-2) are 0.3306 and 0.0349 by the banking sector variables. For South Africa, the VAR model estimate in table 4.4, Banking Sector Development Model of FI shows that the estimate of $\beta_{1}$ is -0.0081 which implies that there is negative relationship between the loan and advances (SLOA) and foreign investment (SFI) in South Africa. Increase in SLOA by a unit will result in 0.01 decrease in South Africa foreign investment (SFI). The estimate of $\beta_{2}$ is 1.8468 which indicates that there is direct relationship between the independent variable, interest rate (SINT) and foreign Investment (SFI); suggests that a unit change in interest rate (SINT) will account for about 1.8 decrease in foreign investment (SFI). The coefficient of $\beta_{3}=2.264$ represents the estimated value of domestic credit (SDC) indicating positive relationship of foreign investment (SFI) and domestic credit. Therefore, a unit change in SDC results in 2.26 increases in foreign investment (SFI). Return on investment (SROI) has estimated coefficient of $\beta_{4}=-1.5501$ indicating negative relationship between SROI and SFI. Change in ROI will result in 1.55 decrease of FI in South Africa. The value of SFI (-1) and SFI (-2) are -0.5419 and 0.3721 by the banking sector variables. However, the banking sector variables are significant to the foreign investment in South Africa (SFI) both in the previous and current years with T-stat. value of 2.82 and -2.08 which is greater than the '2-t' significance value. Banking sector variables have long run equilibrium relationship with foreign investment in Nigeria.

Table 4.5: Results of VAR Model of FI Global Statistics Model Summary for Nigeria

\begin{tabular}{|c|c|c|}
\hline & Nigeria & South Africa \\
\hline Global Statistics & BSD & BSD \\
\hline R-squared & 0.7219 & 0.6891 \\
\hline Correlation R & 0.8485 & 0.8246 \\
\hline
\end{tabular}




\begin{tabular}{|c|c|c|}
\hline Adj. R-squared & 0.6593 & 0.5905 \\
\hline F-statistic & $62.95^{* *}$ & $3491.97^{* *}$ \\
\hline Log likelihood & 1.5869 & 11.8186 \\
\hline Akaike AIC & 1.9788 & 2.9738 \\
\hline Mean dependent & 3.9520 & 7.9679 \\
\hline S.D. dependent & 4.2727 & 8.2885 \\
\hline
\end{tabular}

**Sig. if F-stat < F-tab. Value of 2.51, Source: E-Views statistical package version 7

To evaluate the significance of the individual macroeconomic variables on the foreign investment in Nigeria, the result outputs of the VAR Model adopts '2-t'-statistic based on the rule of thumb to measure the significance of the banking sector development variables to the foreign investment. The values of t-statistics for the coefficient of SLOA, SINT and SROI are $-0.015,0.74$ and -0.74 respectively and are less than 2.0 rule of thumb irrespective of sign difference. Therefore, the null hypotheses are accepted; economic indicators - SLOA, SINT and SROI are not statistically significant to FI but SINT attracts FI in South Africa. SDC indicator attracts FI and it is significant at 5\%. For Nigeria, BSD - Banking Sector Development Model on FI has very high R-Squares values of $72.2 \%$ with the Adjusted R-squares values of $65.9 \%$. The F-stat of the BSD model is greater than 2.51 F-table value at $5 \%$. Therefore, Banking Sector Development Model is statistically significance at 5\% level. The value of Akaike Information Criterion - AIC is 1.98 and it is fitted at $87.9 \%$. NDC is statistically significant to FI in Nigeria as the t-stat. (2.58) is greater than the rule of thumb.

\subsection{Operational model of banking sector development}

The operational Model is used to predict the value of foreign investment in Nigeria and South Africa based on the respective economic indicators. The models are stated below with the economic indicators' values and the FI prediction values.

\section{Predicted BSD Model Result}

$$
\begin{aligned}
& \text { Let } L O A=24.8, I N T=3.2, D C=4.1, R O I=2.9 \\
& S F I=-122.55-0.008 S L O A+1.85 S I N T+2.26 S D C-1.55 S R O I \\
& S F I=-12.55-0.008(24.8)+2.25(3.2)+2.26(4.1)-1.55(2.9) \\
& S F I=-0.77 \\
& N F I=6.36+0.32 N L O A+0.06 N I N T+0.19 N D C-0.01 N R O I \\
& N F I=6.36+0.32(24.8)+0.06(3.2)+0.19(4.1)-0.01(2.9) \\
& N F I=26.70
\end{aligned}
$$

Banking sector model economic indicators reveal that the indicators positively attracts foreign investment inflows into Nigeria but repels foreign investment in South Africa (the predicted total values (26.7 and -0.77) foreign investment inflows into Nigeria and South Africa).

\section{Summary of findings}

General objectives of this study were to critically examine the impact of macroeconomic variables on foreign investment inflows in Africa using Nigeria and South Africa cases with data from 1980 to 2013. The main findings of the research study are summarized as follows:

Loan and Advances (LOA), Interest rate (INT) and Domestic credit (DC) affect positively on foreign investment in Nigeria. ROI negatively affects FI. In South Africa, return on investment (ROI) and LOA have negative effect on SFI. SDC and INT affected positively on FI. In terms of banking sector indicators, foreign interest is attracted by NLOA, NINT and NDC in Nigeria while NROI repels foreign interest. DC and INT attract FI but ROI and LOA repels FI in South Africa. The result shows that there is no longrun equilibrium relationship between BSD indicators and FI in Nigeria and South Africa.

Based on Akaike information - criteria for best model selection, the empirical finding shows that Banking Sector Development Model (BSD) has the best model indicators for attracting foreign investment in Nigeria than it does in South Africa. 


\section{Conclusion and recommendations}

From the findings above, the followings are the main conclusion identified from the empirical analysis. The main foreign investment determinants based on the developing models are company income tax, value added tax, export, Market capitalisation, domestic credit from private and financial sectors, ratio domestic to GDP and economic growth in Nigeria. Export, custom and excise duty tax, company income tax, value added tax, market capitalisation and domestic to GDP are the major foreign investment attraction variables in South Africa. In general, the study has been able to establish that the main foreign investment indicators with respect to the two countries model development are, Major economic component tax system (MECTS), Company income tax (CIT) and Custom and excise duty (CEDT), Domestic credit, exchange rate, total listing of stock and equity, total value of transaction, agriculture and services. The driving forces among the trade liberalization operations attracting foreign investment is exchange rate in Nigeria and South Africa. (Is this smt related to this conducted research? Seems nothing relevant)

I deleted here a part called "Recommendation" and merged it with conclusion.

From the empirical findings of the study, the following recommendations are made: To encourage foreign investment in Nigeria and South Africa, sincere effort is needed by government and the private individual; to promote sustainable domestic credit facilities to local industries to attract foreign investment, government should be proactive in ensuring effective interest rate control to encourage loans and advances. Utmost importance is the enactment of workable policies to discourage high inflation and increase efficient interest rate system among local and foreign investors in Nigeria and South Africa with a view of boosting the nation's infant industries, which will in turn generate employment and income.

\section{References}

- Akujuobi .L.E. (2006). Investment Analysis. Owerri, Nigeria: Adyudo Press.

- Ali A. (2012). Banking Sector Development and Economic Growth in Lebanon. International Research Journal of Finance and Economics. ISSN 1450-2887 Issue 100. http://www.internationalresearchjournaloffinanceandeconomics.com

- Angela S, Ini S.U, Audu S., Ngozi V.A and Baba N.Y (2014). Developing Banking System Stability Index for Nigeria. CBN Journal of Applied Statisics Vol. 5 No. 1.

- Anupam .B. and Krishna .S. (2002). "Foreign Direct Investment in Sub-Sahara African Country and Investigation of 29 Sub-Sahara African Countries in Senegal" (1980-2000)

- Aremu .J.A. (2007). Foreign Private Investment: Determinants, Performance and Promotion. CBN Bulletin, 108 - 112.

- Central Bank of Nigeria Statistical Bulletin 2013

- Gurley, J.G. and Shaw, E.S.(2008), "Financial Aspects of Economic Development", American

- Economic review, vol. 45, setembro, pp. 515 - 538.

- Harsch, E. (2014). South Africa: White Rule, Black Revolt. New York: Monad.

- Leonce N. (2005). Can Macroeconomic Policy Stimulate Private Investment in South-Africa? New Insights From Aggregate and Manufacturing Sector Level Evidence. University of Massachusetts 200 Hicks Way Amherst, MA 01003.

- Menike L.M.C.S (2006), "The Effect of Macroeconomic Variables on FDI in Emerging Sri Lankan Stock market" Sabaragamuwa University Journal, Vol.6, No 1, pp 50-67

- Mohammed S.D, Hussain .A., Jalil M.A, and Ali A. (2009), "Impact of Macroeconomic Variables on Stock Prices: Empirical Evidence in case of KSE (Karachi Stock Exchange)". European Journal of Scientific Research ISSN 1450-216X Vol. 38 No 1 (2009), PP. 96-103.

- Nwezeaku N.C (2005). Taxation in Nigeria Principles \& Practics. Springfield Publishers Ltd, Owerri, Imo State.

- Nzotta .S.M (2005), “Corporate Financial Decisions.” Oliverson Industrial Publishers, 14 Mbonu Ojike Street,Owerri, Imo State - Nigeria.

- Okolie C.M (2000). Foreign Investment Scramble. Magazine on Nigeria's Economy and World Business. Vol. 1 No. 12.

- Okongwu (1989). Foreign Investment Scramble. 1989 Budget Full Report and Analysis.

- Onuorah A.C and Okoli M. N (2013), "Long Run Relationship Between Macroeconomic Variables and FDI in Nigeria", Developing Country Studies Vol. 3, No.1. International Institute for Science, Technology \& Education (IISTE).

- Onuorah, A. C and Akujobi, L. E (2013) Impact of Macroeconomic Indicators on the 
Performance of Foreign Portfolio Investment in Nigeria, European Journal of Business and Management, Academic research Vol 5, No 2.

- South Africa Growth Employment and Redistribution Policy GERP (1996). Investment Strategies in Emerging Markets.

- South-Africa Business Fact Mission Sheet (2012): Netherlands- African Business

- South-Africa Economic Development Program (SAEDP).

- South-Africa Statistical Bulletin 2013.

- Treisman, D. (2007), "Foreign Investment in Africa"

- World Bank, (2002), "World Development Indicators CD-Rom".

- World Bank, World Development Indicators (2013) 